\title{
Patient-Centered Care and Associated Factors at Public and Private Hospitals of Addis Ababa: Patients' Perspective
}

\author{
Frehiwot Birhanu' \\ Kiddus Yitbarek $\mathbb{D D}^{2}$ \\ Animut Addis $\mathbb{D}^{2}$ \\ Dereje Alemayehu' \\ Nigusie Shifera (D) \\ 'Department of Health Service \\ Management, School of Public Health, \\ College of Health Science, Mizan-Tepi \\ University, Mizan-Aman, Ethiopia; \\ ${ }^{2}$ Department of Health Policy and \\ Management, Faculty of Public Health, \\ Jimma University, Jimma, Ethiopia
}

Background: Patient-centered care is a practice of caring for patients in ways that are valuable to the individual patient and families. Implementation of the practice is a common problem worldwide. In Ethiopia, the available information is limited and is largely skewed to certain dimensions of the practice.

Objective: To assess the patient-centered health care practice and associated factors among public and private general hospitals of Addis Ababa 2020.

Methods: An institution-based comparative cross-sectional study was conducted in two public, and seven private general hospitals located in Addis Ababa from April 08 to May 20, 2020. A multistage sampling technique was employed to select the study participants. Data were collected using an interviewer-administered structured questioner, then entered into Epi-data version 3.1, and finally analyzed using SPSS version 25. Multivariable logistic regression was used to identify independent predictors of clients' perceived patient-centered care. Statistical significance was declared at $\mathrm{p}$-value $<0.05$ and adjusted odds ratio with $95 \%$ confidence interval. Results: A total of 570 patients were involved with $99.8 \%$ response rate. About $49 \%$ (95\% CI: $45.0-53.1)$ of patients rated the practice as good. It was $27.8 \%$ (95\% CI: $22.5-33.1)$, and 70.2\% (95\% CI: 64.6-75.4) for public, and private hospitals, respectively Hospital type (AOR:0.21; 95\% CI: 0.13-0.35), service easiness (AOR:3.3; 95\% CI: 2.0-5.8), hospital attractiveness (AOR:2.3; 95\% CI: 1.2,4.5), privacy to access care (AOR:2.0; 95\% CI: $1.1,4.1$ ), information on plan of care (AOR:2.3; 95\% CI; 1.1,4.6), information on medication (AOR:3.1; 95\% CI; 1.5,6.3), and perceived intimacy with the provider (AOR: $0.4 ; 95 \%$ $\mathrm{CI} ; 0.2,0.8)$ were the factors associated with the practice.

Conclusion: Even though providing patient-centered care has been the focus of quality improvement in Ethiopia, this study showed it is mostly being implemented from the traditional provider-centered approach and public hospitals were lower in practice than private hospitals.

Keywords: patient-centered care, public hospitals, private hospitals

\section{Introduction}

Patient-centered care (PCC), according to the three most influential models, is a practice of caring for patients in ways that are meaningful and valuable to the individual patient and families.

The Picker institute model uses respect for patients' needs and preferences, attention to physical comfort, coordination and integration of care, transition and continuity of care, emotional support, accessibility of care, information and
Correspondence: Frehiwot Birhanu Department of Health Service

Management, School of Public Health College of Health Science, Mizan-Tep University, PO Box 260, Mizan-Aman, Ethiopia

Email frehiwotb2017@gmail.com 
education for patients, and family and friends involvement to define and measure the patient-centeredness of the care. ${ }^{1}$

Advancements in medicine in the 21st century have shifted from the patient's problem to disease processes and a decline in focus on a patient. This resulted in despite the increasing scope and advancement in healthcare worldwide, it is largely fallen short in addressing the problem related to the quality of care. ${ }^{2,3}$

For instance, a survey in the US showed that one-third of the sick patients left the doctor's office without getting answers. And in a report from five other developed countries, about half of the patients were not participating in a clinical decision. ${ }^{4}$

In Low- and Middle-Income Countries (LMIC), the PCC is found to be limited and it is indicated that private health facilities provide more client-oriented care than public ones. ${ }^{5-7}$ A study conducted in different African countries also confirmed a provider-centered relationship. Similarly, users of private hospitals in different African countries reported better satisfaction in the domains of responsiveness than public hospital users. ${ }^{8-10}$

While we are tempted to blame poor practice and compassionless care on the individual doctor or nurse delivering the care, it is known that the organizational context and patient's demographic characteristics can make a difference in how the care is delivered or experienced. A report from the Picker institute elaborates on the quality of the built environment and information technology influences the practice of PCC. ${ }^{11-13}$

There is plenty of evidence that supports PCC enhances patient's health outcomes in many ways: increasing patient satisfaction, building trust, bringing favorable behavioral change, improving treatment adherence, and more active patient self-management. ${ }^{14,15}$ This will have an associated economic gain through fewer diagnostic tests, fewer referrals, and less cost of non-adherence. ${ }^{16,17}$

Even though the available information in Ethiopia is largely skewed to certain dimensions of PCC those studies suggest; provision of adequate information, patient empowerment, family and friend involvement, accessibility of care, and physical comfort; to be far from the existing practice. ${ }^{18-20}$

Knowing the level of PCC is very important for concerned stakeholders for future planning. However, in Ethiopia, the available information about the practice as well as the differences between public and private hospitals is very limited. Therefore, this research was designed to fill the information gap and pave the way for decisionmakers to support evidence-based planning.

\section{Methods}

\section{Study Setting, Design, and Period}

A health institution-based comparative cross-sectional study was conducted at the public and private general hospitals of Addis Ababa, the capital of Ethiopia. The city is where headquarter of African Union (AU) is located. Geographically, Addis Ababa is located 9 1' 48" North latitude, and $38^{\circ} 44^{\prime} 24^{\prime \prime}$ East longitude with a total area of 527 square kilometers. Based on the 2019 population projection, Addis Ababa has a total estimated population size of 7,823,600. There are a total of 5 public and 22 private general hospitals in the city. We conducted the study between April 8 and May 20, 2020.

\section{Population and Sampling}

The source population for this study was all admitted patients at public and private general hospitals of Addis Ababa during the study period. Those patients admitted for more than or equal to 24 hours in the wards of the hospital were eligible for the study. There are a total of twentyseven general hospitals in the city ( 5 public and 22 private). Two and seven hospitals, $30 \%$ from each group, were selected using a simple random technique from public and private general hospitals, respectively. We then determined the sample size for the study using a double population proportion formula with assumptions like the proportion of PCC practice at public hospitals $=0.50$, and proportion of $\mathrm{PCC}$ practice at private hospitals $=0.65$. The overall proportion then became 0.575 , considering the mean of the two. Furthermore, we considered a $95 \%$ confidence level, and a power of $80 \%$.

$$
\begin{aligned}
& \mathbf{n}=\mathbf{2}\left(\mathbf{Z}_{\alpha / \mathbf{2}}+\mathbf{Z}_{\beta}\right)^{\mathbf{2}} / \delta^{\mathbf{2 2 1}} \\
& =173 \text { for each group } \\
& \text { Where, }
\end{aligned}
$$

$\mathrm{Z} \alpha / 2$ is the critical value of the normal distribution at $\alpha /$ 2 (for a confidence level of $95 \%, \alpha$ is 0.05 and the critical value is 1.96 )

$\mathrm{Z} \beta$ is the critical value of the normal distribution at $\beta$ (for a power of $80 \%, \beta$ is 0.2 and the critical value is 0.84 )

$\delta$ is $\mathrm{p} 1-\mathrm{p} 2 /(\sqrt{\mathrm{P}}(1-\mathrm{P}))$

Considering the design effect of 1.5 and $10 \%$ nonresponse rate, the final sample size became 570. A total of 285 samples were allocated to each of the public and private hospitals. The calculated sample size was then 
proportionally allocated to the size of the average monthly inpatient flow in the respective hospital. To determine the average monthly patient flow, we took the consecutive three-month inpatient history of the hospitals. Finally, we employed a systematic random sampling method to identify study participants. The sampling interval (K) was calculated by dividing the average inpatient flow of the hospital by the size of the allocated sample size [Table 1].

\section{Study Variables and Measurement}

The dependent variable for this study is patient-centered health care practice ( $\mathrm{PCHCP}$ )

The independent variables were Patients' Sociodemographic characteristics; (Age, educational status, gender, marital status, income); Perceived organizational related factors (Welcoming space to patient and family, Easiness to access services within the institution, Sound and noise, Beauty, and external appearances, Privacy to access care, Communication on the plan of care, safety alert, diet, and medication); and Perceived self and healthcare provider-related factors (Perceived intimacy with the provider, Self-perception towards clinical knowledge, and Perception of physician competency).

\section{Measures and Operational Definitions}

Easiness to access services within the institution: is a perception by the respondent whether there were difficulties or not to access medical services. Patients were classified as having a "good" perception if responded very good and good; and "poor" perception if responded either neutral, poor, or very poor.

Beauty and external appearance: is the perception of the respondents whether the hospital was looking good or not, and patients were classified as having "good" perception if responded very good and good; and "poor" perception if responded either neutral, poor, or very poor.

Privacy to access care: is the perception by the respondents whether they had sufficient privacy or not, and patients were classified as having "good" perception if responded very good and good; and "poor" perception if responded either neutral, poor, or very poor.

Communication on the plan of care: is a perception by the respondents whether a piece of clear information was delivered regarding the plan of care during their hospital stay and they were classified as having "good" perception if responded very good and good; and "poor" perception if responded either neutral, poor, or very poor.

Medication information: is a perception by the respondents whether a piece of information was provided about when to take, how to take, and how much at a time to take medications or not and "good" perception is categorized as a response of very good and good; and "poor" perception if responded either neutral, poor, or very poor.

Perceived intimacy with the provider: is thought by the respondent that he/she knows the health care provider. And it was measured with one yes or no item.

PCHCP: is a perception by respondents whether the health care was involved and/or comfortable for the patient, families, and friends or not. It was measured with 34 items structured questionnaire with responses structured by a five-point scale. And, respondents were categorized as experiencing a "good PCHCP" if responded above or equal to the median score and "poor PCHCP" if responded below the median score. ${ }^{22}$

Table I Proportional Allocation of Sample Size to Public and Private General Hospitals of Addis Ababa, Ethiopia, 2020 (N=570)

\begin{tabular}{|l|l|l|l|}
\hline \multicolumn{2}{|l|}{ Public Hospitals (N= 285) } & Sample & Private Hospitals (N= 285) \\
\hline Hospital & $378 / 678 * 285=159$ & Hospital & $43 / 225 * 285=54$ \\
\hline$\bullet$ Zewditu General hospital & $300 / 678 * 285=126$ & $\bullet$ Nddis Hiwot General hospital & $20 / 225 * 285=25$ \\
\hline - Ghandi General Hospital & & $\bullet$ ICMC General hospital & $39 / 225 * 285=49$ \\
\hline & & $\bullet$ Saint Yared General hospital & $27 / 225 * 285=34$ \\
\hline & & $\bullet$ Kadisco General hospital & $25 / 225 * 285=32$ \\
\hline & $\bullet$ Amin General hospital & $37 / 225 * 285=47$ \\
\hline & $\bullet$ Landmark General hospital & $34 / 225 * 285=44$ \\
\hline
\end{tabular}




\section{Data Collection Tools and Procedures}

Data were collected using an adapted intervieweradministered structured questionnaire. The tool has four sections. Section one: Patient sociodemographic characteristics, Section two: PCC measuring questions that were originally developed by Jane M. and Anna P. in collaboration with Erasmus School of Health Policy \& Management, Erasmus University, Netherlands. ${ }^{23}$ The reliability of the tool was checked by researchers and Cronbach's $\alpha$ for measuring patient-centered care was 0.89. Section three: Perceived organizational-related factors; nine items that have five-point Likert scale items, Section four: Perceived patient and provider-related factors; four items with yes or no question. [Supplementary File 1]

The questionnaire was translated into the local language Amharic and then a pre-test was carried out on $5 \%$ (29) of the sample at Jimma Medical Center. The training was given for data collectors, and supervisors for two days about the objectives of the study, contents of the data collection tool, procedures of data collection, and research ethics. The respondents were interviewed upon discharge.

\section{Data Management and Analysis}

The data were entered into Epi Data version 3.1 and exported to SPSS version 25 for analysis. Binary Logistics regression was used to identify factors associated with PCHCP. All variables having a P-value $\leq$ of 0.25 during the bivariate analysis were considered as candidates for the multivariable logistic regression. After the multivariable logistic regression analysis variables having p-values $<0.05$ were considered as having a statistically significant association with PCHCP. A multicollinearity test was conducted and there was no multicollinearity between variables with a maximum VIF of 1.9. The goodness of fit of the final model was checked using the Hosmer-Lemeshow test of goodness of fit considering good fit at P-value $>0.05$, and also omnibus likelihood test at $<0.05$ and model classification of accuracy was checked. Finally, the degree of association was assessed by using AOR with 95\% CI. The findings were presented with tables, graphs, and frequencies.

\section{Ethical Statement}

The study was approved by the Research and Ethics Committee, of Jimma University Institute of Health with an IRB Number of IRB/00039/2020. The relevant offices of the selected hospitals were then communicated for their cooperation with a formal letter issued by the Research and Ethics Committee of Addis Ababa Public Health Research and Emergency Management Directorate. The objectives, procedure, duration, possible risks, and benefits of the study were clearly explained for study participants, and then written informed consent was obtained from each respondent before data collection. For participants whose age is less than 18 informed consent was obtained from the parents or cake giver of the child. Any study participant willing to engage in the study and those who wanted to stop an interview at any time were allowed to do so. This study was conducted in accordance with the Declaration of Helsinki.

\section{Result}

\section{Socio-Demographic and Economic Characteristics}

About 569 participants (284 from public hospitals, and 285 from private hospitals) were involved in the study with a response rate of $99.8 \%$. In both public and private hospitals, females were dominant $(53.1 \%$ and $52.9 \%)$ in number, respectively. The age of the study participants ranges from a 2 years old child to an 85 years old adult with a mean age of 36 years $( \pm 15.4$ years). About half of the study participants from both private $147(51.5 \%)$ and public $134(47.1 \%)$ hospitals were married. Regarding their educational status, the highest proportion of $99(34.8 \%)$ of study participants of public hospitals have attended an elementary education, among the private hospital users; however, the highest proportion $122(42.8 \%)$ have attended higher education and above. The total monthly income of the study participants ranges from no income to ETB 25,000 with a median income of ETB $5000( \pm 3832)$ [Table 2].

\section{Perceived Organizational Related Factors}

The majority of $255(89.4 \%$ ) of the study participants from private hospitals perceived the hospital had a welcoming space, and about three-fifths $176(61.9 \%)$ of public hospital users perceived the same.

On the other hand, around three quarter 220(77.1\%) of participants from private hospitals perceived it was easy to access services in the hospital; however, less than a half $127(44.7 \%)$ of participants from public hospitals felt the same. Similarly, the external appearance of the hospital 
Table 2 Socio-Demographic Characteristics of the Respondents at Public and Private General Hospitals of Addis Ababa, Ethiopia $2020(N=570)$

\begin{tabular}{|c|c|c|c|c|c|}
\hline \multicolumn{2}{|l|}{ Variable } & \multirow[t]{2}{*}{ Poor PCHCP } & \multirow[t]{2}{*}{ Good PCHCP } & \multirow[t]{2}{*}{ COR (95\%) } & \multirow[t]{2}{*}{ Sig (p-value) } \\
\hline Category & Name & & & & \\
\hline Sex & $\begin{array}{l}\text { Male } \\
\text { Female }\end{array}$ & $\begin{array}{l}145 \\
145\end{array}$ & $\begin{array}{l}122 \\
157\end{array}$ & $\begin{array}{l}1.28(0.9,1.7) \\
\text { । }\end{array}$ & 0.13 \\
\hline Age & $\begin{array}{l}<15 \\
15-19 \\
20-24 \\
25-29 \\
30-34 \\
35-39 \\
40-44 \\
45-49 \\
50-54 \\
55-59 \\
>60\end{array}$ & $\begin{array}{l}22 \\
14 \\
20 \\
39 \\
54 \\
42 \\
41 \\
22 \\
13 \\
6 \\
17\end{array}$ & $\begin{array}{l}29 \\
16 \\
25 \\
31 \\
33 \\
19 \\
38 \\
26 \\
11 \\
15 \\
36\end{array}$ & $\begin{array}{l}0.99(0.9,1.1) \\
1.8(0.7,4.6) \\
1.6(0.7,3.8) \\
2.6(1.2,5.6) \\
3.4(1.6,7.1) \\
4.6(2.1,10.3) \\
2.2(1.0,4.7) \\
1.7(0.7,4.0) \\
2.5(0.9,6.7) \\
0.8(0.2,2.5) \\
1\end{array}$ & $\begin{array}{l}0.24 \\
0.18 \\
0.21 \\
0.01 \\
0.00 \\
0.00 \\
0.26 \\
0.15 \\
0.26 \\
0.76 \\
0.03\end{array}$ \\
\hline Marital status & $\begin{array}{l}\text { Single } \\
\text { Married } \\
\text { Divorced } \\
\text { Widowed }\end{array}$ & $\begin{array}{l}88 \\
146 \\
27 \\
29\end{array}$ & $\begin{array}{l}95 \\
135 \\
18 \\
31\end{array}$ & $\begin{array}{l}0.9(0.5, I .7) \\
I . I(0.6,2.0) \\
I .6(0.7,3.5) \\
I\end{array}$ & $\begin{array}{l}0.9 \\
0.6 \\
0.26 \\
0.5\end{array}$ \\
\hline Educational status & $\begin{array}{l}\text { No education } \\
\text { Elementary } \\
\text { Secondary } \\
\text { Above secondary }\end{array}$ & $\begin{array}{l}46 \\
80 \\
71 \\
93\end{array}$ & $\begin{array}{l}41 \\
85 \\
70 \\
83\end{array}$ & $\begin{array}{l}I \\
I(0.5, I .6) \\
0.8(0.5, I .2) \\
0.9(0.5, I .4)\end{array}$ & $\begin{array}{l}0.8 \\
0.9 \\
0.4 \\
0.6\end{array}$ \\
\hline Income (ETH Birr) & $\begin{array}{l}<5000 \\
5000-10,000 \\
10,000-15,000 \\
15,000-20,000 \\
20,000-25,000 \\
>25,000\end{array}$ & $\begin{array}{l}170 \\
89 \\
23 \\
4 \\
3 \\
1\end{array}$ & $\begin{array}{l}138 \\
98 \\
16 \\
8 \\
11 \\
8\end{array}$ & $\begin{array}{l}\text { I } \\
9.8(0.2,7.9) \\
7.2(0.8,5.9) \\
11.5(0.3,10.1) \\
4(0.3,4.4) \\
2.1(0.1,2.5)\end{array}$ & $\begin{array}{l}0.26 \\
0.34 \\
0.44 \\
0.28 \\
0.43 \\
0.32\end{array}$ \\
\hline
\end{tabular}

was perceived to be good-looking in more than three fourth $234(82.1 \%)$ of private hospital users whereas in around three-fifth $169(59.5 \%)$ of public hospital users. More than three fourth $238(83.5 \%)$ of private hospital participants perceived there was sufficient privacy to access care in the hospital, on the contrary about half $150(52.8 \%)$ of public hospital participants perceived it in the same way [Table 3].

\section{Perceived Self and Physician-Related Factors}

Almost comparable $83(31.2 \%)$ and $79(27.8 \%)$ of the respondents from private and public hospitals, respectively, know their health care provider. On the other hand, of around two-fifth 131(45.9\%), 124(43.6\%) of patients from private and public hospitals think they are aware of their disease. Coming to awareness on treatment options nearly half $160(56.1 \%), 144(50.7 \%)$ of private and public hospital respondents think they have awareness about the treatment options, respectively [Table 4].

\section{The Status of Patient-Centered Health Care Practice at Public and Private General Hospitals}

The mean value of PCHCP was found to be $131( \pm 20)$, and the median was 135 . The value ranges from a minimum value of 75 up to a maximum value of 170 . The result showed a majority of the respondents 290 (51\%); [95\% 
Table 3 Perceived Organizational Related Factors That Might Affect the Patient-Centered Health Care Practice at Public and Private General Hospitals of Addis Ababa, Ethiopia, 2020 $(\mathrm{N}=570)$

\begin{tabular}{|c|c|c|c|c|}
\hline \multirow[t]{2}{*}{ Item } & \multicolumn{2}{|l|}{ Public } & \multicolumn{2}{|c|}{ Private } \\
\hline & $\begin{array}{l}\text { Good } \\
{[\%]}\end{array}$ & $\begin{array}{l}\text { Poor } \\
{[\%]}\end{array}$ & $\begin{array}{l}\text { Good } \\
{[\%]}\end{array}$ & $\begin{array}{l}\text { Poor } \\
{[\%]}\end{array}$ \\
\hline $\begin{array}{l}\text { Welcoming space to the } \\
\text { patients }\end{array}$ & $\begin{array}{l}176 \\
{[61.9]}\end{array}$ & $\begin{array}{l}108 \\
{[38.1]}\end{array}$ & $\begin{array}{l}255 \\
{[89.4]}\end{array}$ & $\begin{array}{l}30 \\
{[10.6]}\end{array}$ \\
\hline $\begin{array}{l}\text { Easiness to access services in } \\
\text { the hospital }\end{array}$ & $\begin{array}{l}127 \\
{[44.7]}\end{array}$ & $\begin{array}{l}\text { I57 } \\
{[55.2]}\end{array}$ & $\begin{array}{l}220 \\
{[77.1]}\end{array}$ & $\begin{array}{l}65 \\
{[22.8]}\end{array}$ \\
\hline $\begin{array}{l}\text { Sound and noise in the } \\
\text { hospital }\end{array}$ & $\begin{array}{l}69 \\
{[24.3]}\end{array}$ & $\begin{array}{l}215 \\
{[75.7]}\end{array}$ & $\begin{array}{l}29 \\
{[10.1]}\end{array}$ & $\begin{array}{l}256 \\
{[89.8]}\end{array}$ \\
\hline $\begin{array}{l}\text { The external appearance of } \\
\text { the hospital }\end{array}$ & $\begin{array}{l}169 \\
{[59.5]}\end{array}$ & $\begin{array}{l}\text { II5 } \\
{[40.4]}\end{array}$ & $\begin{array}{l}234 \\
{[82.1]}\end{array}$ & $\begin{array}{l}51 \\
{[17.8]}\end{array}$ \\
\hline $\begin{array}{l}\text { Privacy to access services in } \\
\text { the hospital }\end{array}$ & $\begin{array}{l}150 \\
{[52.8]}\end{array}$ & $\begin{array}{l}134 \\
{[47.1]}\end{array}$ & $\begin{array}{l}238 \\
{[83.5]}\end{array}$ & $\begin{array}{l}47 \\
{[16.4]}\end{array}$ \\
\hline $\begin{array}{l}\text { Communication on the plan } \\
\text { of care }\end{array}$ & $\begin{array}{l}169 \\
{[59.5]}\end{array}$ & $\begin{array}{l}115 \\
{[40.5]}\end{array}$ & $\begin{array}{l}237 \\
{[83.1]}\end{array}$ & $\begin{array}{l}48 \\
{[16.8]}\end{array}$ \\
\hline $\begin{array}{l}\text { Communication on safety } \\
\text { alert }\end{array}$ & $\begin{array}{l}188 \\
{[66.2]}\end{array}$ & $\begin{array}{l}96 \\
{[33.8]}\end{array}$ & $\begin{array}{l}237 \\
{[83.1]}\end{array}$ & $\begin{array}{l}48 \\
{[16.8]}\end{array}$ \\
\hline Communication on diet & $\begin{array}{l}183 \\
{[64.4]}\end{array}$ & $\begin{array}{l}\text { I0I } \\
{[35.5]}\end{array}$ & $\begin{array}{l}236 \\
{[82.8]}\end{array}$ & $\begin{array}{l}49 \\
{[17.1]}\end{array}$ \\
\hline $\begin{array}{l}\text { Communication on } \\
\text { medication }\end{array}$ & $\begin{array}{l}194 \\
{[68.3]}\end{array}$ & $\begin{array}{l}90 \\
{[31.6]}\end{array}$ & $\begin{array}{l}231 \\
{[81.0]}\end{array}$ & $\begin{array}{l}54 \\
{[18.9]}\end{array}$ \\
\hline
\end{tabular}

CI: 47.3-54.7] rated the overall status of PCHCP in general hospitals of Addis Ababa poor. And the rest 279 (49\%); [95\% CI: 45.3-52.7] rated the service well.

There is a statistical significant difference in PCHCP among public and private general hospitals of Addis Ababa; it was $27.8 \%$ (95\% CI: $22.5-33.1)$ and $70.2 \%$ (95\% CI: 64.6-75.4), (p-value $<0.001), \quad$ respectively [Figure 1].

\section{Factors Associated with \\ Patient-Centered Health Care Practice}

Our simple logistic regression analysis has identified variables like type of the hospital, sex of the patient, age of the respondent, marital status, hospital's space for the patients, easiness to access service, noise in the hospital, the attractiveness of the hospital, privacy to access care, information on the plan of care, information on a safety alert, information on diet, information on medication, perceived intimacy with the provider, awareness on one's disease,
Table 4 Perceived Self and Provider-Related Factors That Might Affect the Practice of Patient-Centered Health Care Practice at Public and Private General Hospitals of Addis Ababa, Ethiopia $2020(\mathrm{~N}=570)$

\begin{tabular}{|l|l|l|l|l|}
\hline \multirow{2}{*}{ Item } & \multicolumn{2}{|l|}{ Public } & \multicolumn{2}{l|}{ Private } \\
\cline { 2 - 5 } & $\begin{array}{l}\text { Yes } \\
{[\%]}\end{array}$ & $\begin{array}{l}\text { No } \\
{[\%]}\end{array}$ & $\begin{array}{l}\text { Yes } \\
{[\%]}\end{array}$ & $\begin{array}{l}\text { No } \\
{[\%]}\end{array}$ \\
\hline Knowing the provider & 79 & 205 & 89 & 196 \\
{$[27.8 \%]$} & {$[72.1 \%]$} & {$[31.2 \%]$} & {$[68.7 \%]$} \\
\hline $\begin{array}{l}\text { Awareness of one's } \\
\text { disease }\end{array}$ & $\begin{array}{l}124 \\
{[43.6 \%]}\end{array}$ & $\begin{array}{l}160 \\
{[56.3 \%]}\end{array}$ & $\begin{array}{l}13 \mid \\
{[45.9 \%]}\end{array}$ & $\begin{array}{l}154 \\
{[54.0 \%]}\end{array}$ \\
\hline $\begin{array}{l}\text { Awareness of treatment } \\
\text { options available }\end{array}$ & $\begin{array}{l}144 \\
{[50.7 \%]}\end{array}$ & $\begin{array}{l}140 \\
{[49.2 \%]}\end{array}$ & $\begin{array}{l}160 \\
{[56.1 \%]}\end{array}$ & $\begin{array}{l}125 \\
{[43.8 \%]}\end{array}$ \\
\hline $\begin{array}{l}\text { Perceived physician's } \\
\text { knowledge }\end{array}$ & 232 & 52 & $\begin{array}{l}270 \\
{[94.7 \%]}\end{array}$ & $\begin{array}{l}15 \\
{[5.2 \%]}\end{array}$ \\
\hline
\end{tabular}

awareness on treatment options and perceived physician knowledge.

Patients from private hospitals were $79 \%$ less likely to perceive the care encountered as "poor" than that of the public hospital users (AOR: 0.21 ; 95\% CI: 0.13-$0.35)$. On the other hand as compared to patients who perceived it was easy to access services, those who perceived the opposite were 3.3 times more likely to perceive the care as "poor" (AOR: 3.3; 95\% CI: 2.0-5.8). In another way, patients who perceived the hospital was not looking good were 2.3 times more likely to perceive the care encountered as "poor" (AOR: 2.3; 95\% CI: 1.2-4.5) than their counterparts. And as compared to patients who perceived there was good privacy in the hospital those who perceived the opposite were 2 times more likely to perceive the care as "poor" (AOR:2; 95\% CI: 1.1-4.1). On the other hand, patients who perceived there was poor education on medication were 3.1 times more likely to perceive the care encountered as "poor" (AOR: 3.1; 95\% CI: 1.5-6.3) than patients who perceived it good. And as compared to patients who perceived there was good communication on the plan of care, those who perceived it poor were 2.3 times more likely to perceive the care encountered as "poor" (AOR: 2.3; 95\% CI: 1.1-4.6). Finally, patients who think they know the health care provider were $60 \%$ less likely to perceive the health care encounter as "poor" (AOR: 0.4; 95\% CI: 0.2-0.8) [Table 5]. 
The status of patient-centered health care practice among public and private general hospitals of Addis Ababa, June 2020

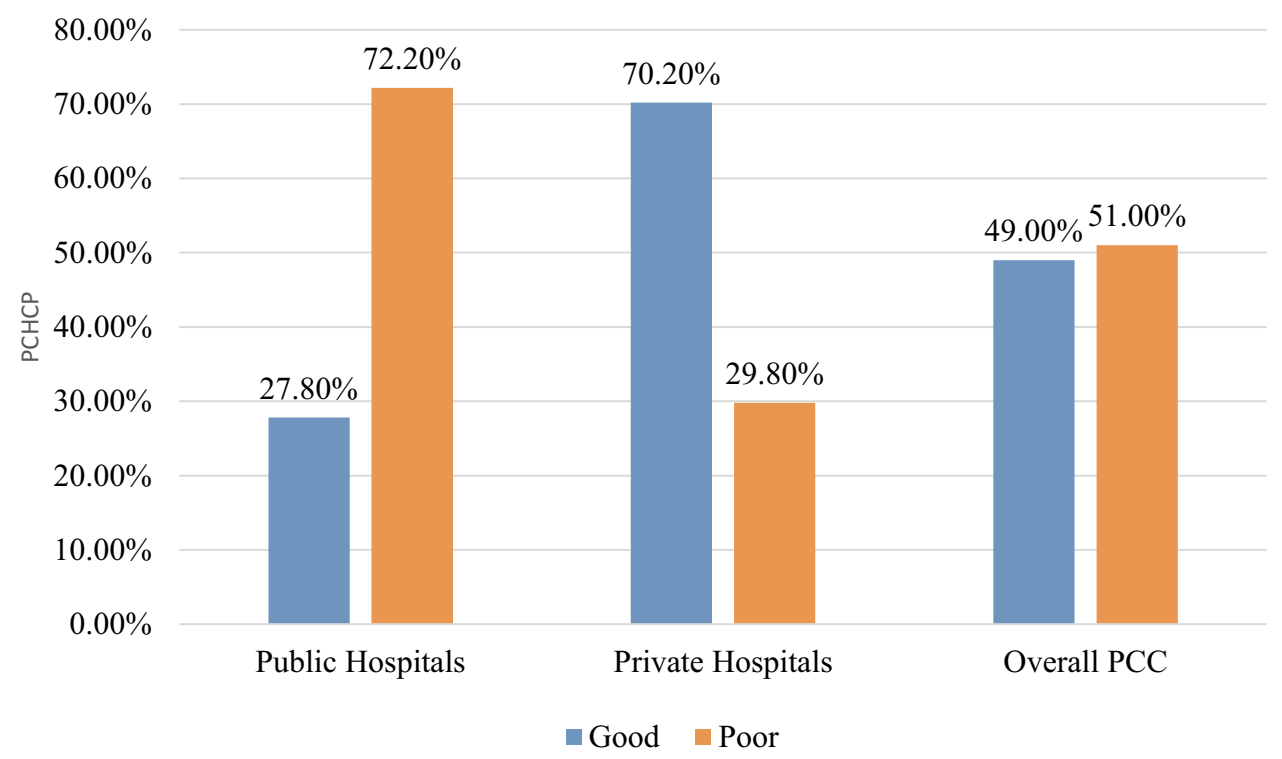

Figure I The overall status of patient-centered health care practice at public and private general hospitals of Addis $\mathrm{Ababa,} 2020$ ( $\mathrm{N}=570$ ).

\section{Discussion}

Patient-centered care is introduced in health service organizations to actively participate patients (clients) in their medical treatment in close cooperation with the health professionals. According to various studies, this approach of care has resulted in a better health outcome and satisfaction of clients. In this study, we have assessed how patients in public and private hospitals perceived the PCHCP and the factors that might affect their perception of good or poor practice.

In this study, $51 \%$ of respondents perceived the $\mathrm{PCHCP}$ as "poor". This finding is lower than a crosssectional study conducted in Tigray regional state, Ethiopia. In this study, the experience of PCHCP was perceived as "poor" in $45 \%$ of the respondents. ${ }^{24}$ This difference might be due to the wider aspects of the PCHCP measuring tool, used in this study, with dimensions that are at a grassroots level of implementation in our country. ${ }^{20}$ On the other hand, this finding was in line with a report by a National Healthcare Quality Agency which states PCC was reported "always" used in only $45-62 \%$ of patient encounters. ${ }^{25}$ In another study, patients reported the practice of PCC by nurses is to a moderate extent. ${ }^{26}$ This implies the practice is still usually concentrated around what is most convenient for the provider, the payer or the health care organization and not the patient.
The second finding of this study revealed $70.2 \%$, and $27.8 \%$ of patients from private and public hospitals perceived "a good" PCHCP. A survey from South Africa suggests a similar idea. The percentage of patients who rated their experiences with "bad" or "very bad" was $16.8 \%$ for public and $3.2 \%$ for private health institutions. ${ }^{27}$ This disparity may be associated with the public health care system underfunding in the majority of LMIC, which leads to poor information technology and physical environment to support the health workforce and it will lead to staff overburdening and demoralization and finally to a lower PCHCP. ${ }^{28}$

In the light of identifying factors that might affect the PCHCP organizational-related factors, including easiness to access service, the attractiveness of the hospital, privacy to access care, communication on the plan of care, and communication on medication found to have a statistically significant association with PCHCP. This finding brought the main assumption that PCHCP is enabled through the quality of interaction between the health care providers, the patient, and most importantly the health care organization delivering the care, into the light. The reason being, organizational context is particularly pertinent in shaping and mediating how the care is delivered, experienced, and perceived. ${ }^{13,28,29}$

On the other hand, patients who think they know their health care provider had a $60 \%$ lower chance of perceiving 
Table 5 Factors That are Associated with Patient-Centered Care at Public and Private Hospitals of Addis Ababa, Ethiopia 2020 $(\mathrm{N}=570)$

\begin{tabular}{|c|c|c|c|c|c|c|}
\hline \multicolumn{2}{|l|}{ Variable } & \multirow[t]{2}{*}{ Poor PCHCP } & \multirow[t]{2}{*}{ Good PCHCP } & \multirow[t]{2}{*}{ COR (95\%) } & \multirow[t]{2}{*}{ AOR (95\%) } & \multirow[t]{2}{*}{ Sig (p-value) } \\
\hline Category & Name & & & & & \\
\hline Type of the hospital & $\begin{array}{l}\text { Private } \\
\text { Public }\end{array}$ & $\begin{array}{l}85 \\
205\end{array}$ & $\begin{array}{l}200 \\
79\end{array}$ & $\begin{array}{l}0.16(0.1,0.2) \\
1\end{array}$ & $\begin{array}{l}0.21(0.13,0.35) \\
I\end{array}$ & $<0.00 I^{*}$ \\
\hline Sex & $\begin{array}{l}\text { Male } \\
\text { Female }\end{array}$ & $\begin{array}{l}145 \\
145\end{array}$ & $\begin{array}{l}122 \\
157\end{array}$ & $\begin{array}{l}1.28(0.9,1.7) \\
1\end{array}$ & $\begin{array}{l}1.2(0.7,2.0) \\
1\end{array}$ & 0.3 \\
\hline Age & $\begin{array}{l}\text { Below mean } \\
\text { Above mean }\end{array}$ & $\begin{array}{l}168 \\
122\end{array}$ & $\begin{array}{l}145 \\
134\end{array}$ & $\begin{array}{l}1.2(0.9,1.7) \\
1\end{array}$ & $\begin{array}{l}\text { I.I }(0.5,2.1) \\
\text { I }\end{array}$ & 0.7 \\
\hline Organizational space & $\begin{array}{l}\text { Poor } \\
\text { Good }\end{array}$ & $\begin{array}{l}189 \\
101\end{array}$ & $\begin{array}{l}11 \\
268\end{array}$ & $\begin{array}{l}18.9(9,36) \\
1\end{array}$ & $\begin{array}{l}1.9(0.8,4.5) \\
1\end{array}$ & 0.1 \\
\hline Service easiness & $\begin{array}{l}\text { Poor } \\
\text { Good }\end{array}$ & $\begin{array}{l}189 \\
101\end{array}$ & $\begin{array}{l}33 \\
246\end{array}$ & $\begin{array}{l}\mid 3.9(9-2 \mid) \\
\mid\end{array}$ & $\begin{array}{l}3.3(1.9,5.8) \\
1\end{array}$ & $<0.001 *$ \\
\hline Noise & $\begin{array}{l}\text { Disagree } \\
\text { Agree }\end{array}$ & $\begin{array}{l}228 \\
62\end{array}$ & $\begin{array}{l}243 \\
36\end{array}$ & $\begin{array}{l}\text { I } \\
0.5(0.3,0.8)\end{array}$ & $1.5(0.8,2.8)$ & 0.1 \\
\hline Attractiveness & $\begin{array}{l}\text { Poor } \\
\text { Good }\end{array}$ & $\begin{array}{l}143 \\
147\end{array}$ & $\begin{array}{l}23 \\
256\end{array}$ & $\begin{array}{l}10.8(6.6, \mid 7.5) \\
\text { । }\end{array}$ & $\begin{array}{l}2.3(1.1,4.5) \\
I\end{array}$ & $0.01 *$ \\
\hline Privacy & $\begin{array}{l}\text { Poor } \\
\text { Good }\end{array}$ & $\begin{array}{l}160 \\
130\end{array}$ & $\begin{array}{l}21 \\
258\end{array}$ & $\begin{array}{l}15(9.1,24.1) \\
1\end{array}$ & $\begin{array}{l}2.0(1.1,4.0) \\
1\end{array}$ & $0.03^{*}$ \\
\hline Information on plan of care & $\begin{array}{l}\text { Poor } \\
\text { Good }\end{array}$ & $\begin{array}{l}146 \\
144\end{array}$ & $\begin{array}{l}17 \\
262\end{array}$ & $\begin{array}{l}15.6(9.1,26) \\
1\end{array}$ & $\begin{array}{l}2.3(1.1,4.6) \\
I\end{array}$ & $0.0 I^{*}$ \\
\hline Information on safety alert & $\begin{array}{l}\text { Poor } \\
\text { Good }\end{array}$ & $\begin{array}{l}130 \\
14\end{array}$ & $\begin{array}{l}160 \\
265\end{array}$ & $\begin{array}{l}\text { I5.3(8.5,27.6) } \\
\mid\end{array}$ & $\begin{array}{l}1.0(0.4,2.7) \\
\text { । }\end{array}$ & 0.8 \\
\hline Information on diet & $\begin{array}{l}\text { Poor } \\
\text { Good }\end{array}$ & $\begin{array}{l}135 \\
15\end{array}$ & $\begin{array}{l}155 \\
264\end{array}$ & $\begin{array}{l}15.3(8.6,27) \\
\mid\end{array}$ & $\begin{array}{l}\text { I } \\
\text { I.I }(04,12)\end{array}$ & 0.6 \\
\hline Information on medication & $\begin{array}{l}\text { Poor } \\
\text { Good }\end{array}$ & $\begin{array}{l}128 \\
16\end{array}$ & $\begin{array}{l}162 \\
263\end{array}$ & $\begin{array}{l}\text { I2.9(7.4,22.6) } \\
\text { | }\end{array}$ & $\begin{array}{l}3.1(1.5,6.3) \\
1\end{array}$ & $0.002 *$ \\
\hline Knowing the provider & $\begin{array}{l}\text { No } \\
\text { Yes }\end{array}$ & $\begin{array}{l}247 \\
43\end{array}$ & $\begin{array}{l}154 \\
125\end{array}$ & $\begin{array}{l}1 \\
0.2(0.1,0.3)\end{array}$ & $\begin{array}{l}\text { I } \\
0.4(0.2,0.8)\end{array}$ & $0.000 *$ \\
\hline Awareness on one's disease & $\begin{array}{l}\text { Yes } \\
\text { No }\end{array}$ & $\begin{array}{l}92 \\
198\end{array}$ & $\begin{array}{l}163 \\
116\end{array}$ & $\begin{array}{l}0.3(0.2,0.4) \\
I\end{array}$ & $\begin{array}{l}0.7(0.4,1.2) \\
1\end{array}$ & 0.3 \\
\hline Awareness on treatment options & $\begin{array}{l}\text { Yes } \\
\text { No }\end{array}$ & $\begin{array}{l}117 \\
173\end{array}$ & $\begin{array}{l}187 \\
92\end{array}$ & $\begin{array}{l}0.33(0.2,0.4) \\
1\end{array}$ & $\begin{array}{l}0.7(0.3,1.3) \\
I\end{array}$ & 0.3 \\
\hline Physician's competency & $\begin{array}{l}\text { Yes } \\
\text { No }\end{array}$ & $\begin{array}{l}226 \\
64\end{array}$ & $\begin{array}{l}276 \\
3\end{array}$ & $\begin{array}{l}0.03(0.01,0.12) \\
1\end{array}$ & $\begin{array}{l}0.2(0.05,0.9) \\
1\end{array}$ & 0.6 \\
\hline
\end{tabular}

Notes: *Indicates p value $<0.05$, I: reference categories.

their encounter as "poor". This finding is consistent with a study conducted in central Ethiopia which states patients who perceive they know their health care provider was experiencing a 2 fold of better empathic care. ${ }^{12,30}$ It implies that perceived intimacy with the provider has a direct relation with PCC encounter.

\section{Limitation of the Study}

In reading our findings, the readers need to consider the following limitations. In this study, the PCHCP is measured from the patients' point of view in the compound of the health facility which has a probability to make their response more prone to social desirability bias. To 
minimize this bias, we did not recruit data collectors from the respective institutions.

\section{Conclusion and Recommendation}

This study showed the overall perceived PCHCP was poor in the highest proportion of study participants. Even though providing PCC has been the focus of quality improvement in our country in recent years, it is mostly being implemented from the provider-centered, and disease-focused approach. Even if the main source for medical services in LMIC is publicly provided health facilities, public hospitals in this study were performing low. The Federal Ministry of Health should give thorough attention to improve the practice by making a positive influence on factors that are believed to be important enablers of the practice. Especially in public health facilities.

\section{Abbreviations}

LMIC, low and middle-income countries; PCC, patientcentered care; PCHCP, patient-centered health care practice.

\section{Data Sharing Statement}

The datasets were generated and analyzed during the study and will make the data sets available to organizations and individuals based on reasonable request.

\section{Acknowledgments}

The authors are grateful to Jimma University for their support in conducting this study. Special thanks also go to selected public and private hospitals for their cooperation throughout the data collection period. Finally, the author would like to acknowledge research assistants and study participants for their valuable time, and cooperation.

\section{Author Contributions}

All authors made a significant contribution to the work reported, whether that is in the conception, study design, execution, acquisition of data, analysis, and interpretation, or in all these areas; took part in drafting, revising, or critically reviewing the article; gave final approval of the version to be published; have agreed on the journal to which the article has been submitted; and agree to be accountable for all aspects of the work.

\section{Funding}

The study was funded by Jimma University.

\section{Disclosure}

The authors reported no conflicts of interest for this work.

\section{References}

1. McCormack B. Person-centredness in gerontological nursing: an overview of the literature. J Clin Nurs. 2004;13:31-38. doi:10.1111/ j.1365-2702.2004.00924.x

2. Haslam DA. Who cares? The James Mackenzie lecture 2006. Br J Gen Pract. 2007;57(545):987-993. doi:10.3399/096016407782604884

3. Barry MJ, Edgman-Levitan S. Shared decision making - the pinnacle patient-centered care. 2012.

4. Schoen C, Osborn R, Huynh PT, et al. Primary care and health system performance: adults' experiences in five countries: differing performance levels among countries highlight the potential for improvement and cross-national learning. Health Aff. 2004;23 (Supp11):W4-W484-503. doi:10.1377/hlthaff.W4.487

5. Pongsupap Y, Lerberghe WV. Choosing between public and private or between hospital and primary care: responsiveness, patient-centredness and prescribing patterns in outpatient consultations in Bangkok. Trop Med Int Health. 2006;11(1):81-89. doi:10.1111/ j.1365-3156.2005.01532.x

6. Berendes S, Heywood P, Oliver S, Garner P. Quality of private and public ambulatory health care in low and middle income countries: systematic review of comparative studies. PLoS Med. 2011;8(4): e1000433. doi:10.1371/journal.pmed.1000433

7. Rannan-Eliya RP, Wijemanne N, Liyanage IK, et al. The quality of outpatient primary care in public and private sectors in Sri Lankahow well do patient perceptions match reality and what are the implications? Health Policy Plan. 2015;30(suppl_1):i59-i74. doi:10.1093/heapol/czu115

8. Yannick J, de Sardan Jean-pierre O. Une médecine inhospitalière: Les difficiles relations entre soignants et soignés dans cinq capitales d'Afrique de l'Ouest. Karthala Editions; 2003.

9. Adesanya T, Gbolahan O, Ghannam O, et al. Exploring the responsiveness of public and private hospitals in Lagos, Nigeria. $J$ Public Health Res. 2012;1(1):2. doi:10.4081/jphr.2012.e2

10. Mthanti SM. Exploring the Healthcare Service Quality in a Provincial Hospital. North-West University (South Africa): Potchefstroom Campus; 2015.

11. Mannion R, Davies H. Understanding organisational culture for healthcare quality improvement. $B M J .2018 ; 363: 363$. doi:10.1136/bmj.k4907

12. Birhanu Z, Assefa T, Woldie M, Morankar S. Predictors of perceived empathy among patients visiting primary health-care centers in central Ethiopia. Int J Qual Health Care. 2012;24(2):161-168. doi:10.1093/intqhe/mzs001

13. Shaller D. Patient-Centered Care: What Does It Take? New York: Commonwealth Fund; 2007.

14. Zolnierek KBH, DiMatteo MR. Physician communication and patient adherence to treatment: a meta-analysis. Med Care. 2009;47(8):826. doi:10.1097/MLR.0b013e31819a5acc

15. Beck RS, Daughtridge R, Sloane PD. Physician-patient communication in the primary care office: a systematic review. J Am Board Fam Med. 2002;15(1):25-38.

16. Bertakis KD, Azari R. Patient-centered care is associated with decreased health care utilization. J Am Board Fam Med. 2011;24 (3):229-239. doi:10.3122/jabfm.2011.03.100170

17. Robinson JH, Callister LC, Berry JA, Dearing KA. Patient-centered care and adherence: definitions and applications to improve outcomes. J Am Acad Nurse Pract. 2008;20(12):600-607. doi:10.1111/ j.1745-7599.2008.00360.x

18. Asefa A, Bekele D. Status of respectful and non-abusive care during facility-based childbirth in a hospital and health centers in Addis Ababa, Ethiopia. Reprod Health. 2015;12(1):33. doi:10.1186/ s12978-015-0024-9 
19. Gebremichael MW, Worku A, Medhanyie AA, Edin K, Berhane Y. Women suffer more from disrespectful and abusive care than from the labour pain itself: a qualitative study from Women's perspective. BMC Pregnancy Childbirth. 2018;18(1):392. doi:10.1186/s12884018-2026-4

20. Tamiru Bogale T, Beharu M, Tesfaye T, Belay Y. Scope of patient centered care practice in public hospitals of Benishangul Gumuze regional state, south West Ethiopia. Qual Prim Care. 2018;26 (1):31-37.

21. Hajian-Tilaki K. Sample size estimation in epidemiologic studies. Casp J Intern Med. 2011;2(4):289.

22. Manikandan S. Measures of central tendency: median and mode. J Pharmacol Pharmacother. 2011;2(3):214. doi:10.4103/0976$500 \mathrm{X} .83300$

23. Cramm JM, Nieboer AP. Validation of an instrument for the assessment of patient-centred care among patients with multimorbidity in the primary care setting: the 36 -item patient-centred primary care instrument. BMC Fam Pract. 2018;19(1):143. doi:10.1186/s12875018-0832-4

24. Berhe H, Berhe H, Bayray A, Godifay H, Beedemariam G. Status of caring, respectful and compassionate health care practice in Tigrai regional state: patients' perspective. Int J Caring Sci. 2017;10 (3):1119.
25. US Department of Health and Human Services. Agency for Healthcare Research and Quality (2005) National Healthcare Disparities Report. Rockville (Maryland): Agency for Healthcare Research and Quality Publication; 2008.

26. Poochikian-Sarkissian S, Sidani S, Ferguson-Pare M, Doran D. Examining the relationship between patient-centred care and outcomes. Can J Neurosci Nurs. 2010;32(4):14-21.

27. Peltzer K. Patient experiences and health system responsiveness in South Africa. BMC Health Serv Res. 2009;9(1):117. doi:10.1186/ 1472-6963-9-117

28. Luxford K, Safran DG, Delbanco T. Promoting patient-centered care: a qualitative study of facilitators and barriers in healthcare organizations with a reputation for improving the patient experience. Int J Qual Health Care. 2011;23(5):510-515. doi:10.1093/intqhe/ mzr024

29. Mannion R. Enabling compassionate healthcare: perils, prospects and perspectives. Int $J$ Health Policy Manag. 2014;2(3):115. doi:10.15171/ijhpm.2014.34

30. Baker R, Boulton M, Windridge $\mathrm{K}$, Tarrant C, Bankart J, Freeman GK. Interpersonal continuity of care: a cross-sectional survey of primary care patients' preferences and their experiences. $\mathrm{Br}$ J Gen Pract. 2007;57(537):283-290.

\section{Publish your work in this journal}

Patient Related Outcome Measures is an international, peer-reviewed, open access journal focusing on treatment outcomes specifically relevant to patients. All aspects of patient care are addressed within the journal and practitioners from all disciplines are invited to submit their work as well as healthcare researchers and patient support groups.
The manuscript management system is completely online and includes a very quick and fair peer-review system. Visit http://www. dovepress.com/testimonials.php to read real quotes from published authors. 